\title{
US and Vietnam join forces to count cost of Agent Orange
}

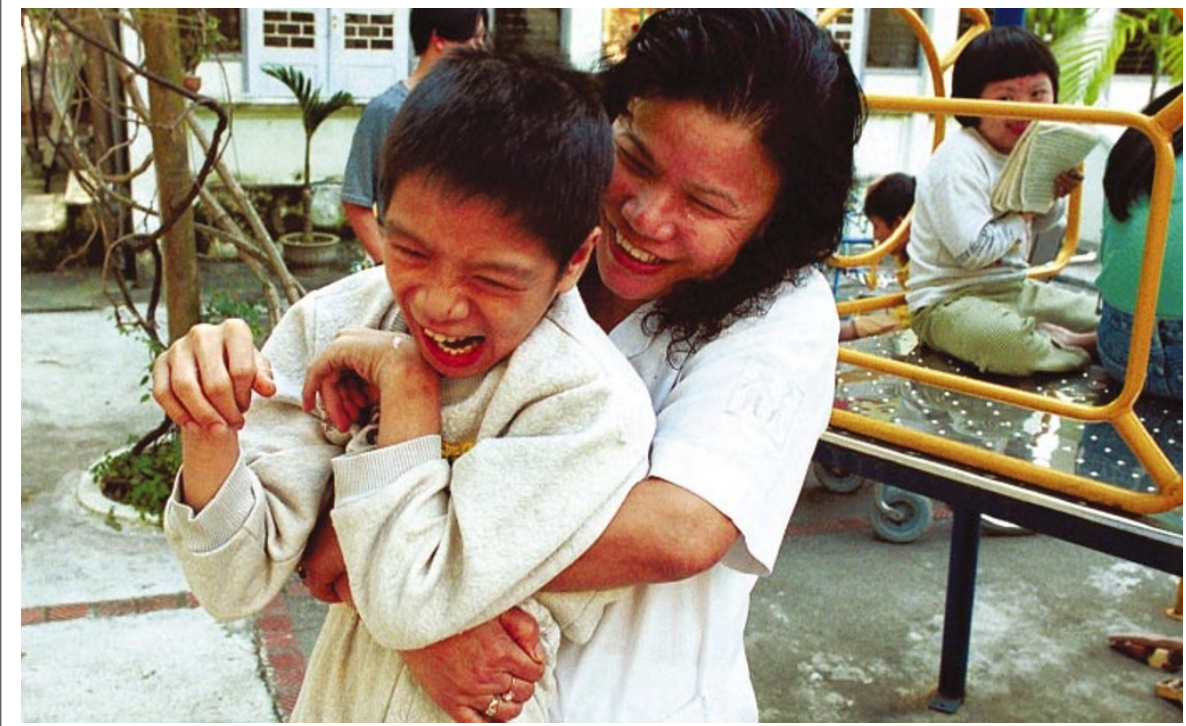

Pollution by defoliating chemicals has been blamed for causing birth defects among Vietnam's children.

David Cyranoski, Tokyo

A joint research programme to investigate the damage caused by the defoliant Agent Orange is set to be launched by the United States and Vietnam.

But with no special funding - and with some government officials on both sides said to be keen to keep details of the damage under wraps - some experts doubt whether the project can get to the bottom of the health and environmental problems caused by the chemical. Used by the US military in the Vietnam War, Agent Orange has left a legacy of dioxin pollution - which has been linked to cancer, immune disorders and birth defects — in some parts of Vietnam.

On 10 March, following a four-day conference in Hanoi which brought together epidemiologists, toxicologists and environmental scientists from 13 countries (see Nature 413, 442;2001), the United States and Vietnam signed a memo formally establishing the joint research programme.

Chris Portier, director of the environmental toxicology programme at the US National Institute of Environmental Health Sciences, says that he is encouraged by the agreement. "We have always had a good relationship with the Vietnamese scientists, and now the Vietnamese government has become more comfortable with us," he says.

Vietnamese researchers were likewise optimistic. "The scientists of the two countries will work together and will see the damages suffered by the Vietnamese people," says Hoang Trong Quynh, director of Vietnam's Center for Ecologically Sustainable Agriculture. The findings of the research will "strongly support a humanitarian reso- lution from the US side", Quynh adds.

The agreement sets up a US-Vietnam advisory committee that will arrange researcher visits, meetings and exchanges of graduate students. But the lack of special funding for the programme means that researchers will have to apply for support through the usual channels at agencies such as the US National Institutes of Health.

Critics claim that the Vietnamese government placed restrictions on who could participate at the Hanoi meeting. According to one delegate, the government is worried that the monitoring of dioxin levels in fish and seafood caught off the coast of Vietnam might damage exports. As a result, this participant claims that "there were no open discussions" at the meeting.

This and other complaints about the joint effort are set to come under scrutiny at a meeting in Stockholm this July, which will be attended by many of those who went to Hanoi. Al Burke, editor of the Nordic News Network, who is organizing the Stockholm meeting, claims that "many legal and ethical issues are being avoided because the United States doesn't want to deal with them".

But researchers at the Hanoi meeting say that the joint programme will lead to better research on Agent Orange's health and environmental effects. Presentations at the conference examined the link between exposure to dioxins and problems such as birth defects, lymphoma, breast cancer, Hodgkin's disease and diabetes. And the US delegation returned from Hanoi with about 20 Vietnamese scientific articles which will be translated into English, and might form the basis for future research projects.

\section{Diplomats near pact in simmering debate over transgenic foods}

Jim Giles, Washington

The European Union (EU) and the United States have taken a small step back from a possible trade war over genetically modified foods.

In negotiations in Yokohama, Japan, which ended on 8 March, representatives from the two sides reached a compromise on how such foods should be monitored. They have just over a year left to reach agreement on other issues, such as how the foods should be labelled for consumers.

The negotiations were part of a threeyear plan to update the Codex Alimentarius, the food-safety standards used by the World Trade Organization (WTO) to settle trade disputes. In Yokohama, the United States dropped its earlier resistance to a system to monitor the movement and health risks of transgenic crops.

The EU currently bans the farming of about 30 US transgenic crop varieties and the importation of foodstuffs containing them. Their suppliers want the United States to file a complaint about the ban with the WTO — but diplomats on both sides hope that such action can be averted by updating the Codex rules.

Alan Randall, secretary of the Romebased Codex commission, warns that the argument is far from over. The two sides are still divided, for instance, over how to deal with foods that are obtained from transgenic plants but which do not themselves contain transferred genes. The EU wants consumers to be told if the food is from a genetically modified source.

Negotiations on such disagreements are scheduled to be completed before a Rome meeting of the Codex commission in July 2003. Randall says there is a long road ahead, but is pleased that an agreement has been reached. "At least the two parties are no longer just shouting at each other," he says. | www.codexalimentarius.net

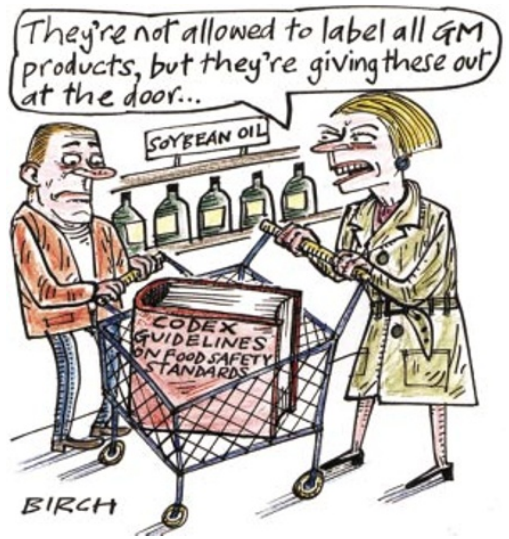

